\title{
Breaking the Chain of Social Injustice through Gender Responsive Civic Education
}

\author{
Fatmariza Fatmariza, Susi Fitria Dewi, Isnarmi Isnarmi, Maria Montessori, Junaidi Indrawadi \\ Pancasila and Civic Education \\ Universitas Negeri Padang \\ Padang, Indonesia \\ fatmariza@fis.unp.ac.id
}

\begin{abstract}
The objective of the research is to analyze the development of awareness about gender equality in students through the learning process of citizenship education. This is one of the strategies to resolve the chain of gender injustice in communities that tend to discriminate against women. This research use qualitative with a participatory action research approach. The subjects are the civic education student's who attend the Perspective Gender class during the semester of JulyDecember 2017. The results show that there are three stages of gender equality awareness of the students. First, to accept the issue of gender inequality within society and the state. Second, respond to the gender inequalities for reasons. The last, analyze gender inequality and giving solutions. The result of the research concluded that there has been a change in gender equality awareness of the students throughout the process of recovery. This condition is assumed can be one of the Efforts in breaking the links of gender inequality and social Injustice, because social Injustice is basically rooted in gender inequality.
\end{abstract}

\section{Keywords-injustice; gender; women; discrimination}

\section{INTRODUCTION}

Gender-based social injustice is a common problem in various countries, especially in developing countries in Asia, Africa, and America. The UN through SDGs (Sustainability Development Goals) targeted be achieved by 2030 still makes gender equality as one of the 17 goals of MDGs (Millennium Development Goals) that should have been achieved by 2015 . The seventeen objectives are (1) no poverty, (2) zero hunger, (3) good health and well-being, (4) quality of education, (5) gender equality, (6) clean water and sanitation, (7) affordable and clean of energy, (8) decent work and economic growth, (9) industry, innovation and infrastructure, (10) sustainable cities and communities, (12) responsible consumption and production, (13) life action, (15) life on land, (16) peace, justice and strong institutions, (17) partnership for the goals. The reality shows the whole countries in the world recognize that gender inequality is a problem in world development. Gender injustice can occur in sixteen SDGs goal because the goal of each goal is the development of human beings both male and female.

The UN has been launching a Gender and Development approach (GAD), which is holistically approach the problem by looking at how societies are organized both economically, politically and culturally as gender social constructs. The gender social construct governs the allocation of roles, attributes, rights, obligations, and responsibilities, and expectations of both men and women. Therefore, the gender awareness and gender sensitivity affect the success of the development. The Planners and the executor development should recognize that women's needs are different from men as a result of gender construction [1]. Thus, it is expected that gender inequalities in various aspects of development can minimize.

As an effort in building gender justice and equality in Indonesia, the government has strengthened the gender mainstreaming in development through the President instruction number 9 in 2000 which made gender mainstreaming as one of strategy in integrating the gender perspective in development. Each institution, both central and regional, should integrate a gender perspective in every policies and program. It is expected to increase gender awareness and gender sensitivity of policymakers and recipient communities so that gender equality and justice can be realized. It means that every person, both government and society, have high gender awareness and gender sensitivity. They realize both men and women are different as a result of social construction but this differences will not create injustice to both men and women.

Various efforts have been made to increase gender awareness of decision makers. One of them is increasing the gender awareness and gender sensitivity among the potential groups which will be able to be agents in the socialization of gender equality and justice in communities. Some research shows that education is one of the significant pathways of gender equality and justice dissemination. However, textbooks and teachers are not gendered sensitive $[2,3,4]$. The handbooks contain bias gender' pictures and phrases. Thus strengthening the belief of women and men are gender differences. Similarly, the treatment of teachers who still tend to be gender biased. Most of these conditions continue to this day, especially for teachers. The curriculum in Pakistan has the potential to perpetuate gender inequality, while lecturers and teachers do not have the understanding and ability to transform gender justice [5]. The same thing was found in Lahelma [6] who examined gender awareness in teacher education institutions 
Based on the description, it can be seen that teachers are potential agents to continue the values that are gender biased and vice versa are also potential to become agents of socializing the values of gender equality and justice. In other words, teachers can become agents of socialization to break the chain of gender injustice if they have gender awareness. Research on efforts to increase gender awareness of teachers has been carried out by several researchers, among them are those conducted by Halai [7]. The findings of the study conclude that gender awareness of teachers can be improved through training of teachers conducted professionally and widely. UNICEF through the peace education program has also included gender training for both schools and NGOs. Other research is an effort to increase gender awareness for children with intellectual disabilities through training to increase their awareness to protect people with disabilities from sexual violence in schools [8].

Unlike previous studies, increasing gender awareness was carried out on prospective teacher students through the learning process in a special gender course. This is one of the strategies that is seen as more effective because early on the prospective teachers have developed gender awareness. Students of the Civic Education Study Program are very strategic to be prepared as agents of socialization of gender equality and justice. Because the substance of civic education is closely related to the rights and obligations of citizens. Thus the civic education students are expected to be both individuals, and later when they become teachers they can become agents of socialization of gender equality and justice in schools through the subjects and activities they develop. Socialization through schools will be relatively more effective because of the more conducive and controlled conditions and school climate.

Analysis of the development of student gender awareness refers to the stages of value development proposed by Anderson and Krathwohl in Wilson [9], which consists of five stages namely accepting, responding, valuing, internalizing and actualizing. This study found that students who have followed the learning process can be grouped into three stages, namely the stage of gender awareness development, or the stage of acknowledging gender injustice, the stage of responding to gender injustice, and the stage of providing solutions to gender inequality as a form of assessment.

\section{RESEARCH METHODS}

This article was written based on a study entitled Growing Student Gender Awareness through Analysis of Gender Issues in Gender Perspectives Course. This study was conducted on Civic education students who took perspective gender subject on Semester July-December 2017. Perspective gender is a subject which offers for fourth- year students. This course aims to equip students with an understanding of gender concepts, objectives and implications in society, related theory, as well as perspectives gender which can be used in analyze injustice phenomenon in many aspects of life, both social, political, economic, legal, etc. which occur at the local, national, or international, can be implemented in research and civic education in schools, and is able to be aware with actualize gender in thinking, acting, and realization of gender equality and justice. In addition, this research conducted only in group
A were consisting of fifty-one students where forty-one of them are women and ten men. This study used a qualitative approach with Participatory Action Research Method. Data were collected through observations, tests, and discussions. This data where validate by using triangulation of data collection techniques. Furthermore, the data analyzed using qualitative analysis of Milles Huberman model.

\section{RESEARCH RESUlT}

Based on data research, student's gender awareness can be group into three categories. First, the group who accept the issue of gender inequality within the community and the state. Second, it responds to gender inequalities for various reasons. Third, analyze gender inequality and find the solutions. In detail, the research findings will be described as follows.

\section{A. Recognition of Gender Injustice}

At the first meeting, each student was asked to list their opinion about ten indicators of male and female. The most ten common indicators of the table below.

TABLE I. GENDER INDICATORS

\begin{tabular}{|l|l|l|}
\hline No & \multicolumn{1}{|c|}{ Man } & \multicolumn{1}{c|}{ Women } \\
\hline 1 & Strong Physical & Soft \\
\hline 2 & Assertive & Patient \\
\hline 3 & Leader & Childbirth \\
\hline 4 & Breadwinner & Breastfeeding \\
\hline 5 & Rational & Emotional \\
\hline 6 & Brave & Whiny \\
\hline 7 & Solider & Coward \\
\hline 8 & Responsible & Fussy \\
\hline 9 & Royal & Housewife \\
\hline 10 & Has sperm & Quitter \\
\hline
\end{tabular}

The table shows that student's opinion about ten indicators for differences between men and women. The students understand that men and women are different. In general, men students are more eager to maintain men and women indicators are different, by contrast, more women students protested against these indicators. This can be observed from the number of women who commented on the indicators paired with men. Sentences such as "not at all, women also can do, women are also capable, etc." indicate the unacceptability of women labeling in the table. However, women students also do not completely reject those indicators. In conclusion, women' students do not accept several women indicators.

After the discussion, students were asked to mark the indicators which do not change and do not interchangeable in both men and women. The result is a categorization of male and female indicators based on the nature of the change. From the male indicators, there is only an indicator that does not change and cannot be exchanged. The indicator is men have sperm. While from the ten indicators of women there are two indispensable indicators of childbirth and breastfeeding. At this stage, the students begin to accept that quite a number of indicators can actually be shared by both men and women. Students begin to understand the concept of sex and gender. Sex is a biological construct brought from birth with different 
reproductive functions between men and women. Meanwhile, gender is the difference between men and women who are constructed by society. Therefore, gender can change over time and the people who construct it.

Furthermore, students are asked to identify possible problems that will arise due to gender differences. Some of the problems identified are: (1) women are under-appreciated, (2) men are prioritized, (3) men dominate, (4) women are given less opportunity, (5) women stay at home, (6) women less trusted, (7) women become victims of domestic violence. Furthermore, students were asked to discuss the issues by comparing the problems experienced by men and the problems experienced by women as a result of gender differences. Based on the results of the discussion, the students concluded that gender differences cause injustice both to men and especially to women.

\section{B. Response to Gender Inequality}

Learning is expected to foster student sensitivity to the problems in the community from a gender perspective. The lecturer modifies the material and activities to build students sensitivity toward gender. In subsequent learning activities, students undertake group work to identify forms of gender inequality, causes and, consequences in people's lives. Each group analyzes gender inequality in one area, law and, policy, politics, employment, education, customs and culture, mass media. Based on the analysis results can be presented as follows:

TABLE II. GENDER EQUALITY ISSUES

\begin{tabular}{|c|c|c|}
\hline No & Field & The issue of gender inequality \\
\hline 1 & Law & $\begin{array}{l}\text { Rape perpetrators are often punished lightly, } \\
\text { women be victims of family violence, less legal } \\
\text { protection against women labours abroad }\end{array}$ \\
\hline 2 & Political & $\begin{array}{l}\text { Few women in the party, it is difficult for women } \\
\text { to be leaders, few of women parliament } \\
\text { members, families permit for women to enter the } \\
\text { party, women are considered less able to lead }\end{array}$ \\
\hline 3 & Employment & $\begin{array}{l}\text { Low salary for women, unpaid working women, } \\
\text { suitable for light workwomen trafficking }\end{array}$ \\
\hline 4 & Education & $\begin{array}{l}\text { Families restrict girls to attend high level of } \\
\text { school, a girl school dropped out for marriage, } \\
\text { helping the family. Women's good at school, but } \\
\text { most job vacancy are looking for and accept the } \\
\text { men. Many women enter the social department } \\
\text { while men enter engineering majors. }\end{array}$ \\
\hline 5 & $\begin{array}{l}\text { Custom and } \\
\text { culture }\end{array}$ & $\begin{array}{l}\text { Low positions for women in several customs, } \\
\text { women are banned from high school, women } \\
\text { become workers in husband's extended family, } \\
\text { men fare in marriage, must have son }\end{array}$ \\
\hline 6 & Mass media & $\begin{array}{l}\text { Ads tend to highlight the physical female, many } \\
\text { soap operas featuring grumpy female, gold } \\
\text { digger, evil, and rarely show a good woman, the } \\
\text { headline in many newspapers that blame women } \\
\text { as victims }\end{array}$ \\
\hline
\end{tabular}

From the data table, it can be seen that students have been able to show the forms of gender injustice in various aspects of society. They have been able to recognize forms of gender injustice in the various aspects such as injustice in law, politics, work, education, customs and culture, and mass media.

\section{The Solution to Gender Inequality}

Based on the observation it can be seen that students' gender sensitivity increasingly continuously. Most of them began responding to the gender issues surround them more quickly, as well as those in their mass media. During the learning process, students are facilitated to be critically thinker and findings the problems solutions of gender inequalities occur in society. Based on the data obtained through discussions and exams can be presented the solutions offered by students. The solution is grouped into two, ie solutions that can be done as individual students and as a citizen. In more detail, the data is described in the table below.

TABLE III. THE SOLUTION TO GENDER INJUSTICE

\begin{tabular}{|l|l|l|}
\hline No & Category & Solution \\
\hline 1 & Individual & $\begin{array}{l}\text { Understanding the gender equity, does not } \\
\text { discriminate the women, gender equality } \\
\text { understanding starts from the family, do not commit } \\
\text { against women violence, respect for women, provide } \\
\text { opportunities for women, take the opportunities to } \\
\text { work, speak for women injustice, deploy insight } \\
\text { gender to family and friends, giving fair treatment to } \\
\text { men and women, }\end{array}$ \\
\hline 2 & Citizen & $\begin{array}{l}\text { educate, speak for gender equality, integrate in } \\
\text { learning, advocate, justice, gender in various } \\
\text { opportunities, become gender responsive } \\
\text { stakeholders, encourage fair regulation, gender } \\
\text { responsive development, empower women, criticize } \\
\text { policies that are not gender responsive, participating } \\
\text { in a women's empowering organization, encouraging } \\
\text { the emergence of fair gender legislation. }\end{array}$ \\
\hline
\end{tabular}

Based on the table, the solutions offered by students can be grouped into several aspects: (1) increasing the knowledge , (2) cultivate a sense of caring or gender sensitiveness in injustice issues, (3) multiplying role model of equality and equity gender, (4) creating equitable gender at home, school, workplace, and community, (5) enhance the care and empowering organizations for women, (6) creating programs and policies that protect and equitable gender, (7) encourage community participation for gender equality and justice in the various sectors and organizations of both social organizations and political organizations.

\section{DISCUSSION}

The gender-based social injustice in this article is a condition of injustice experienced by both men and women as a result of gender differences. Theoretically, Lengerman and Niebrugge in Ritzer and Goodman [10] grouped the root of gender injustice in four categories based on women's positions: gender differences, gender imbalances, gender oppression, and structural oppression. The gender difference is when the women position and their experiences in most situations is different from the men. Gender inequality is where women's position in most situations is not only different but also disadvantaged and unequal to men. In addition, gender oppression is when the women are in a position not only distinguished, unequal, but also actively curbed, subordinated, shaped, used, and abused by men. Furthermore, structural oppression is a woman's experience of discrimination, inequality, and oppression according to her social position. The 
structural suppression occurs when several groups take the advantages directly by control, exploit, subjugate other groups enforced through social structures which in this case is the patriarchal structure.

These conditions indicate that there is a need for strong and tough efforts to reconstruct a new structure more equitable for women. For that purpose, various efforts have been made such as making various laws, policies, programs, and action plans to create equal conditions for women and men in various aspects of life. An effort which considered as an effective way to break the gender inequality is through schools and universities. From the school can be formulated the policies, programs, curriculum, and initiate the gender awareness of teachers and students. In several European countries, the desire to promote gender equality and justice through schools has been going on for decades. However, as mentioned in the introduction, the school also became channels of socialization and defend gender injustice. Durani and Halai [5] showed that the curriculum in Pakistan potentially perpetuate gender inequality, while lecturers and teachers do not have the understanding and ability in transforming gender justice. This conditions also found by Lahelma [6] who examines gender awareness in teacher education institutions. Meanwhile, Halai [7] research shows that teacher gender awareness can be developed through professional and wide-ranging training. In addition, Sibel kucuk, Platin, and Erdem [8] examine the efforts to raise gender awareness in order to protect people with disabilities from sexual violence.

A study of efforts in raising student gender awareness finds three stages of gender awareness development. The stages are recognition of gender inequality, responding to gender inequality, and providing solutions to gender inequality. This stage is also in line with value development stages by Anderson and Krathwohl in Wilson [9] starts with accepting, responding, valuing, internalizing and actualizing. Acceptance or acknowledgment of gender inequality is a form of differentiation awareness between women and men and the difference leads to the injustice against women. Fakih [11] stated that gender inequality affects more women. Further, in minimal, there are five forms of gender inequality, that are: marginalization, subordination, stereotype, double burden, and violence.

In the second stage, both male and female students are able to identify forms of gender inequality. Even in some cases, men are relatively more active and enthusiastic in discussing gender inequalities. It can also be said that the learning which is done by integrating the gender issues have been able to initiate the awareness that gender differences were the cause of injustice against the women. It can be described as an increased awareness of good because theoretically, women tend to give meaning to the reality according to the what is desired by the dominant values in her community. So it is difficult for them to be aware of any injustice which happens to them. In addition, based on the study which was done by Shelly Kowalczyk, Suzanne M. Randolph, Linda Oravecz, shows that genderresponsive policies and systems can improve the health of women and children [12]. That is intervention through policies, systems, and programs to increase awareness of gender individuals or group which in turn can be an agent in promoting gender equality.

\section{CONCLUSION}

Gender differences have not be a problem as long as it won't become injustice. In reality, injustices occur as a result of gender differences. Sociologically, women are not only different in positions and experiences but also less fortunate and unequal to men, even in quite a few cases women are controlled, subordinated, used, abused by men who are institutionalized through a patriarchal structure. Therefore, it is a sustained and continuous effort to transform a lame and patriarchal structure into a just structure for both men and women. These efforts can include socialization, intervention, and integration of equality and gender equity in various sectors including in the education sector. Education as an effective and strategic way to reconstruct new values more equitably for men and women by raising awareness of students, teachers, and lecturers as potential agents in transforming to achieve social justice.

\section{REFERENCES}

[1] Longwee, Sara H. Lupekile "Gender Awarenness: The missing element in the third word development project". In Tria Wallace With Candida March (ed). Changing perceptions: writing on gender and development (p.149-157) oxford:Oxfam, 1991.

[2] Fatmariza. "Pembangunan Gender di Sumatera Barat". Makalah Disampaikan pada acara seminar regional Ecosoc Pembangunan Manusia dan Hak-Hak Warga Negara terhadap Pembangunan di Sumatera Barat 23 Agustus 2004 di Padang, 2004.

[3] Fatmariza. Guru Sekolah Dasar Sebagai Agen Sosialisasi Kesetaraan Gender. Buletin Pembelajaran. Nomor 02 tahun 2001, Juni 2001, 2001.

[4] K. Fatmariza. Analisis Kebijakan Pendidikan Berwawasan Gender dalam rangka Penyusunan Kebijakan Pendidikan Berwawasan Gender di Sumatera Barat II. Dirjend PLS Depdiknas RI, 2004.

[5] N. Durrani, and A. Halai. "Dynamics of gender justice, conflict and social cohesion: Analysing educational reforms in Pakistan". International Journal of Educational Development. journal homepage:www.elsevier.com/locate/ijedudev, 2018.

[6] L. Elina. Gender Awareness in Finnish Teacher Education: an Impossible Mission?. Journal Education Inquiry Volume 2, 2011 - Issue 2. Pages 263-276 | Published online: 01 Jun 2011.

[7] H. Ajum. "Equality or equity: Gender awareness issues in secondary schools in Pakistan". International Journal of Educational Development Volume 31, Issue 1, January 2011, Pages 44-49. 2011.

[8] Sibel K., Nurgun P., Emine E.,. 2017. "Increasing awareness of protection from sexual abuse in children with mild intellectual disabilities: An education study". Applied Nursing Research Volume 38, December 2017.

[9] Wilson. Anderson and Krathwohl-Bloom`s Taxonomy Revised.http. The secondprinciple.com, 2016.

[10] Ritzer, G., and Douglas J. G., Teori Sosiologi Modern six edition Translated by Alimandan from: Modern Sociological theory, 6th edition. Jakarta: Kencana Prenada media group. 2007.

[11] Fakih, M., Membincang Feminisme: diskursus gender perspektif Islam. Risalah Gusti. 1996.

[12] S. Kowalczyk, S. M. Randolph, L. Oravecz, "Community Coalitions' Gender-Aware Policy and Systems Changes to Improve the Health of Women and Girls". Women's Health Issues.Volume 27, Supplement 1, 17 October 2017, Pages S6-S13. 2017. 